\title{
Long-term and millennial-scale climate variability in northwestern France during the last 8850 years
}

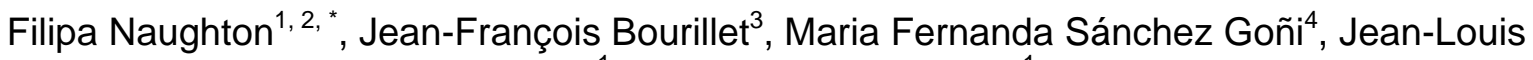 \\ Turon $^{1}$, Jean-Marie Jouanneau ${ }^{1}$
}

\author{
${ }^{1}$ UMR-CNRS EPOC 5805, Bordeaux 1 University, France \\ ${ }^{2}$ Departamento de Geologia, Lisbon University, Portugal \\ 3 IFREMER, Département Géosciences Marines, Laboratoire Environnements Sédimentaires, Plouzané, France \\ ${ }^{4}$ EPHE, UMR-CNRS EPOC 5805, Bordeaux 1 University, France
}

*: Corresponding author : F. Naughton, emai address : f.naughton@epoc.u-bordeaux1.fr

\begin{abstract}
:
Vegetation and quantitative climate reconstructions from a northwestern France shelf core (VK0358Bis) show orbital and suborbital climate variability for the last 8850 years in this region. A long-term cooling trend in summer temperatures, marked by gradual temperate and humid forest decline, parallels cooling in Greenland and the decrease of mid-latitude summer insolation reduction until at least $2000 \mathrm{cal}$. yr BP. At the long-term scale, the lowering in seasonal contrast revealed by vegetation changes follows the increase of precession. Corylus woodlands spread at the expense of deciduous Quercus forest, between 8740 and 8390 cal. yr BP, linked with the high seasonality conditions that, counterbalancing the long-term astronomical forcing trend, were amplified by the north Atlantic high-latitudes winter sea-ice expansion. High seasonality conditions resulted from the Agassiz and Ojibway final outburst episodes and consequent gradual reduction of the Meridional Overturning Circulation (MOC). Between 8390-8060 cal. yr BP, a sudden Corylus woodland decline marks the 8.2 kyr cold event in northwestern France probably triggered by the severe MOC reduction leading to the additional drop in winter temperature over Europe and Greenland. Nonetheless, seasonality remains high during this interval. The high seasonality conditions detected in 'VK03-58Bis' between 8740 and $8060 \mathrm{cal}$. yr BP reflects the multicentennial-scale climate cooling 8.6-8.0 kyr episode of the North Atlantic. Following the Agassiz and Ojibway final outburst episodes, climate became more stable. However, millennial-scale climate cooling episodes are recorded in 'VK03-Bis' and are characterized by weak winter cooling and increases in precipitation. Furthermore, dinocyst analysis and benthic gastropod Turritella communis occurrences indicate regional changes such as the southward migration of the Boreal biogeographical zone between 8740 and $8480 \mathrm{cal}$. yr BP and the subsequent opening of the English Channel at around 8480-8390 cal. yr BP.
\end{abstract}

Keywords: Holocene, long-term cooling, millennial-scale climate variability, $8.2 \mathrm{kyr}$ event, Corylus, marine core, vegetation, Europe, France, Bay of Biscay 


\section{Introduction}

For a long time the Holocene interglacial has been considered a period of stable climate. However, many studies have shown that superimposed on the orbitally-induced long-term cooling (e.g. Kutzbach and Gallimore, 1988; Crucifix et al., 2002; Marchal et al., 2002; Renssen et al., 2005; Lorenz et al., 2006) suborbital millennial scale climate variability has affected this interglacial (e.g. Denton and Karlén, 1973; Barber et al., 1994; O'Brien et al., 1995; Bond et al., 1997; Hughes et al., 2000; 2006; Langdon et al., 2003; Mayewski et al., 2004). The most extreme short-lived cold episode noticed in the Greenland Ice cores (O'Brien et al., 1995; Alley et al., 1997; Muscheler et al., 2004), known as the "8.2-kyr-BP event" and lasting 100-200 years, has been detected elsewhere in several climate proxy data from the North Atlantic marine deep-sea cores (Bond et al., 1997; 2001; Bianchi and McCave; 1999) and from the European continent (e.g. Klitgaard-Kristensen et al., 1998; Von Grafenstein et al., 1998; Nesje and Dahl, 2001; Tinner and Lotter, 2001; 2006; Baldini et al., 2002; Magny et al., 2003; Veski et al., 2004). The causes triggering the "8.2 event" have been strongly debated over the last decade. Some authors suggest that this event results from changes in solar activity (Bond et al., 2001; Van Geel et al., 2003) while others from freshwater pulses (Barber et al., 1999; Von Grafenstein et al., 1999; Rind et al., 2001; Alley et al., 2003). The fact that this event is more prominent in the North Atlantic region, that it follows two outburst flooding episodes, and that the existing similarities between reconstructed anomaly patterns and patterns expected following a North Atlantic freshening seem to favour the freshwater pulse mechanism as the major trigger for the 8.2 event (Alley and Ágústsdóttir, 2005).

Two recent publications (Rohling and Pälike, 2005 and Ellison et al., 2006) suggest that the 8.2 kyr event occurred within a long climate cooling anomaly of multi-centennial-scale, between 8600 and 8000 years ago. This long-lived episode has been previously noticed by a dust supply increase in GISP2 (Mayewski et al., 1997); a decrease of sea surface temperatures (SST) in the North Atlantic (Risebrobakken et al., 2003; Knudsen et al., 2004; Keigwin et al., 2005) and a decrease of annual temperature from a few northern European pollen sequences (Seppä and Poska, 2004) which the authors usually associate with the short-lived 8.2 kyr event.

Besides the $8.2 \mathrm{kyr}$ event, most of the northern European pollen sequences from Estonia and Sweden detect a Holocene Thermal Maximum (HTM) (Seppä and Poska, 2004; Seppä et al., 2005) between 8000 and $4000 \mathrm{cal} \mathrm{yr} \mathrm{BP.}$

So far, no studies have shown the vegetation response either to orbitally-induced long-term cooling or to sub-orbital millennial scale climate variability other than the extreme $8.2 \mathrm{kyr}$ event in western France during the Holocene. The aim of this study is therefore to test whether longer and shorter-term climatic variability, involving the $8.2 \mathrm{kyr}$ event and the 8.6-8.0 kyr episode, has affected this region. Towards this aim, we have performed palynological analyses (pollen and dinocysts) and pollen-derived quantitative climate reconstructions from a shelf core "VK03-58Bis" retrieved in the "Grande Vasière" of the Bay of Biscay. This core gives an integrated image of the past regional vegetation and, therefore, the climate of western France. This region is particularly sensitive to hydrological changes of the North Atlantic Drift (Rahmstorf, 2002).

\section{Environmental Setting}

The Bay of Biscay presents a $300 \mathrm{~km}$ wide continental shelf in it's north-westernmost area and becomes narrow with a steep slope further south (30 km wide) (Figure 1). This shelf is composed of two small and one large open-shelf mud patches: the W and S Gironde shelf mud fields and the "Grande Vasière" (Allen and Castaing, 1977). According to McCave's classification the "Grande Vasière" is a mid-shelf mud belt (McCave, 1972). The "Grande Vasière" is large (more than $225 \mathrm{~km}$ length and $40 \mathrm{~km}$ wide), located between 80 to $110 \mathrm{~m}$ water depth and presents an annual mean sedimentary rate of $0.1-0.2 \mathrm{~cm} \mathrm{yr}^{-1}$ (Lesueur et al., 2001) (Figure 1). Shelf upkeep depends essentially on: a) continental supply by nepheloid layers (Jouanneau et al., 1999; Lesueur et al., 2001); b) wave action (Pinot, 1974) and hydrology, and c) sea level changes (Lesueur and Klingebiel, 1976). The "Grande Vasière" rests over two sandy units and consists of a thin (few decimetres) Holocene feature of muddy autochthon sand (Bourillet et al., 2002). The present day spreading of sediments to the shelf is also influenced by re-suspension and redistribution 
of the sediments during storm episodes and under the effects of trawling nets (Bourillet et al., 2006). The shelf is nourished by fine grained sediments released essentially by the Gironde and Loire rivers and to a lesser extent by the Adour, Vilaine and Charente (Castaing and Jouaneau, 1987). The Gironde and Loire rivers have large catchment areas (including the Massif Central and the Pyrenees zones) recruiting pollen grains from most of the western part of France. Indeed, previous works on world wide coastal zones with complex fluvial systems have shown that pollen grains after being produced and initially dispersed by the wind are mainly transported to the sea by rivers and streams (Muller, 1959; Bottema and Van Straaten, 1966; Peck, 1973; Heusser and Balsam, 1977; Naughton et al., 2007). Experimental studies on pollen from the French margin have shown that river systems are mainly responsible for pollen input into the sea and that the marine pollen signature reflects an integrated image of the regional vegetation of the adjacent continent (Turon, 1984). Furthermore, westerly prevailing winds probably impede direct airborne transport of pollen seaward.

Mean annual precipitation (PANN) over the river basins which represent the pollen catchment area for core "VK03-58Bis" varies from $1000 \mathrm{~mm}$ in the westernmost part to $600 \mathrm{~mm}$ in the eastern zone. Regions at high altitudes, such as the Massif Central are characterised by more than $2200 \mathrm{~mm}$ of PANN while the Pyrenees vary from $2000 \mathrm{~mm}$ in the western part to $1000 \mathrm{~mm}$ in the eastern zone. Present-day annual temperature is $13^{\circ} \mathrm{C}$ in western France (data from French public Agency: "Meteo france").

The oceanic, mild and humid climate of western France allows the development of a temperate deciduous and warm mixed forest mainly composed of deciduous Quercus (Q .pedunculata, Q. pubescens and Q. sessiflora) with some scattered evergreen Quercus (Q. ilex), cork oak (Q. suber) as well as elm (Ulmus) and ash (Fraxinus) associations. Littoral zones are mainly composed of cluster pine (Pinus pinaster) and gorses (Ulex). There are also beech (Fagus) and hornbeam (Carpinus) woodlands at higher altitudes.

\section{Material and methods}

\subsection{Core "VK03-58Bis"}

The $2.72 \mathrm{~m}$ long core, "VK03-58Bis", was retrieved at $96.8 \mathrm{~m}$ water depth in the "Southwest-Glénan" sector of the "La Grande Vasière" mud patch $\left(47^{\circ} 36^{\prime} \mathrm{N}\right.$ and $4^{\circ} 08^{\prime} \mathrm{W}$ ) using a vibrocorer during the "Vibarmor" oceanographic cruise (integrated in the "Défi Golfe de Gascogne" Ifremer programme) (Figure 1). The "Glénan" sector is one of the end members of the "Grande Vasière" and is composed of $3 \mathrm{~m}$ of sediments with high percentages of fine material (greater than $80 \%$ ).

Core description and sedimentological analyses including micro-granulometry, calcimetry, x-ray (SCOPIX image-processing; Migeon et al., 1999) and benthic gastropod Turritella communis counts were performed by Folliot (2004).

\subsection{Radiometric dating}

Five accelerator mass spectrometer (AMS) ${ }^{14} \mathrm{C}$ dates on $\mathrm{T}$. communis were obtained in the Poznan Radiocarbon Laboratory (Poland) (Bourillet et al., 2005), indicating that the "VK03-58Bis" sedimentary sequence covers the last 8850 years (Table I). T. communis dated levels from twin cores, "VK03-58" $\left(47^{\circ} 36^{\prime} \mathrm{N}, 4^{\circ} 08^{\prime} \mathrm{W}\right.$; $97.3 \mathrm{~m}$ water depth) and 'VK03-59Bis" (47 $38^{\circ} \mathrm{N}, 4^{\circ} 09^{\prime} \mathrm{W}$; $94.6 \mathrm{~m}$ water depth), were correlated with that of core "VK03-58Bis" for the age model construction (Figure 2).

All AMS ${ }^{14} \mathrm{C}$ dated levels were calibrated using CALIB Rev 5.0 program and the "global" marine calibration dataset (marine 04.14c) (Stuiver and Reimer, 1993; Hughen et al., 2004; Stuiver et al., 2005). This dataset uses the global marine age reservoir correction (R) of 400 years. For accommodating local effects, we have introduced the difference $\Delta r$ (of about 3 years) in reservoir age of the Bay of Arcachon (France), the closest area to our core, as suggested by Stuiver et al. (2005). We used the 95.4\% (2 sigma) confidence intervals and their relative areas under the probability curve as well as the median probability of the probability distribution (Telford et al., 2004) as suggested by Stuiver et al. (2005). 


\subsection{Pollen and dinocyst analyses}

Multiple samples for pollen and dinocyst analyses (42 and 15 samples, respectively), were collected with a sample spacing of 4 to $8 \mathrm{~cm}$ throughout "VK03-58Bis" sedimentary record. The treatment used for palynological analysis followed the procedure described by de Vernal et al. (1996), slightly modified at the UMR CNRS 5805 EPOC (Unité mixte de Recherche 5805, Centre National de la Recherche Scientifique/Environnement et Paléoenvironnements Océaniques) (Desprat, 2005).

Chemical digestion using cold $\mathrm{HCl}$ (at 10\%, 25\% and 50\%) and cold $\mathrm{HF}$ (at 40\% and 70\%) were applied to eliminate carbonates and silicates. A Lycopodium spike of known concentration was added to each sample to calculate pollen concentrations. The residue was sieved through $10 \mu \mathrm{m}$ nylon mesh screens (Heusser and Stock, 1984) and mounted in bidistillate glycerine. Pollen and cysts were identified and counted using a Zeiss microscope with x550 and x1250 (oil immersion) magnifications, the last one only applied for pollen analysis. At least 100 pollen grains (excluding Pinus, aquatic plants and spores) and at least 15 pollen types were counted. Pinus pollen is usually over-represented in marine deposits and therefore is often excluded from the main sum (Heusser and Balsam, 1977; Turon, 1984). However, it is known that the percentages of this taxa increase seaward although total pollen content decreases (Muller, 1959; Bottema and Van Straaten, 1966; Groot and Groot, 1966; Koreneva, 1966; Van der Kaars and de Deckker, 2003). Because the site location is close to the present-day coast line we assume that Pinus pollen percentages are not over-represented in this core and, therefore, Pinus pollen grains have not been excluded from the main pollen sum.

Pollen percentages of each taxa were calculated based on the main pollen sum that excludes aquatic plants, pteridophyte spores and indeterminable pollen. 57 to 424 cysts were counted and interpreted by comparison with modern dinoflagellate cyst distributions (de Vernal et al., 1998; Rochon et al., 1999).

\subsection{Pollen-based quantitative climate reconstruction}

Quantitative climate reconstruction of north-western of France for the last 8850 years was obtained by applying the modern analogue technique (MAT) (Guiot et al., 1989; Guiot; 1990) to the "VK03-58Bis" pollen sequence. This method is based on a modern pollen assemblage dataset including 1328 pollen spectra from Europe, Eurasia and North Africa (Peyron et al., 1998; Peyron et al., 2005), and it selects the 5 modern pollen assemblages closest to the fossil pollen spectra. These 5 analogues present the smallest chord distance (Guiot, 1990) representing the best modern analogues for a given fossil pollen spectrum and, therefore, the best samples for the estimation of climatic parameters. Climate parameter estimates are obtained by taking a weighted average of the values for all selected best modern analogues which represents the inverse of the chord distance.

Each modern analogue sample is associated with several climate parameters which have been previously interpolated from meteorological stations by using an Artificial Neural Network (ANN) technique (Peyron et al., 1998). The parameters selected for climate reconstruction of north-western France are: TANN (mean annual temperatures); PANN (mean annual precipitation) and the difference between the temperature of the warmest (MTWA) and the coldest (MTCO) months (seasonality). These climate parameters are understood to play a prominent role on the distribution of the vegetation and related pollen assemblages (Peyron et al., 2005).

\section{Results}

\subsection{Lithostratigraphy and age model}

"VK03-58Bis" is characterised by a homogenous silt sequence marked between 210 and $150 \mathrm{~cm}$ by a level containing T. communis (Figure 3). Between 210 and $160 \mathrm{~cm}$ this T. communis community presents all the characteristics of a biocenose: the shells are deposited in life position; both young and adult specimens are present within the same level; they do not present any evidence of shelf destruction by transport. Between 160 and $150 \mathrm{~cm}$, there is an increase in T. communis abundance, and in contrast with the underlying level they are not in life position. This indicates a drastic change in the environmental conditions which probably resulted in their mortality. The age obtained from the bottom of this layer in 
"VK03-58Bis" shelf core is $7630 \mathrm{yr}$ BP (c. $8480 \mathrm{cal}$ yr BP). This single drastic episode has also been observed in the twin cores: "VK03-58" dated at the bottom (7690 yr BP; $8545 \mathrm{cal}$ yr BP) and "VK03-59Bis" (at $4 \mathrm{~km}$ of distance) between 7520 and $7700 \mathrm{yr}$ BP (c. 8380-8550 cal yr BP) (Table I). Considering the shortness of this drastic T. communis mortality episode we can assume that this event has been synchronous in the three cores and, therefore level $150 \mathrm{~cm}$ in "VK03-58Bis" can be correlated with the top of that layer dated at 7520 (c. $8380 \mathrm{cal}$ yr BP) in core "VK03-59Bis" (Figure 2). Because there is no sedimentological evidence (no erosional surfaces from the RX data and continuous grain size decrease) for a hiatus phase after this drastic episode in our core, we decided to reject the date obtained for level $149 \mathrm{~cm}$ which seems too young (6620 yr BP, c. $7510 \mathrm{cal}$ yr BP) when compared with the age limits of the Turritella layer of the twin cores. Furthermore, the pollen record of "VK03-58Bis" shelf core clearly shows the same vegetation succession recorded by continental sequences from both the Massif Central and the Pyrenees confirming that there are neither regional pollen zones missing nor sedimentological gaps.

\subsection{Evolution of dinocyst assemblages}

Dinocyst analysis performed in "VK03-58Bis" between 262 and $98 \mathrm{~cm}$ shows a unique assemblage essentially composed of: Lingulodinium machaerophorum, Operculodinium centrocarpum, and several species of Spiniferites (Spiniferites lazus, Spiniferites bentorii, Spiniferites spp., Spiniferites ramosus, Spiniferites mirabilis, Spiniferites membranaceus, Spiniferites delicatus, Spiniferites bulloideus, Spiniferites belerius, Spiniferites elongates). Spiniferites dominates the dinocyst associations between 262 and $180 \mathrm{~cm}$ and is replaced by Lingulodinium machaerophorum between 180 and $160 \mathrm{~cm}$. A drastic decrease in Lingulodinium machaerophorum is detected between 160 and $150 \mathrm{~cm}$ contemporaneous with the T. communis mortality episode. Finally, and above $150 \mathrm{~cm}$, all species are replaced by Lingulodinium machaerophorum which again completely dominates the dinocyst assemblages (Figure 3).

\subsection{Vegetation succession and quantitative climate reconstruction}

Pollen analysis of the "VK03-58Bis" shelf core records eight main pollen zones (numbered from the bottom to the top and prefixed by the abbreviated sequence name "VK03-58Bis") (Figure 3). The establishment of these 8 pollen zones has been performed by using qualitative fluctuations of a minimum of 2 curves of ecologically important taxa (Pons and Reille, 1986). To delimit each pollen zone chronologically, we have used interpolated ages assuming a constant sedimentary rate between two consecutive dated samples. Figure 4 shows the percentage curves of selected pollen taxa plotted together with the curves of climatic parameter estimates (PANN, MTCO, MTWA, Seasonality and TANN). The first pollen zone (VK03-58Bis-1), 266-245 cm, (c. 7900-7870 yr BP; c. 8855-8810 cal yr BP extrapolated age assuming the same sedimentary rate as that obtained between 226 and $177 \mathrm{~cm}$ ) reflects a Pinus and deciduous Quercus forest with Corylus and Ulmus (Figure 3). Quantitative climate reconstruction shows that TANN and PANN values are 3 to $2^{\circ} \mathrm{C}$ and $200 \mathrm{~mm}$ lower $\left(10-11^{\circ} \mathrm{C}, 600 \mathrm{~mm}\right)$, respectively, than present day values $\left(13^{\circ} \mathrm{C}, 800 \mathrm{~mm}\right.$ ) (Figure 4).

The expansion of deciduous Quercus forest associated with the slight spread of Corylus, Betula and Ulmus and the gradual contraction of pine are indicated by VK03-58Bis-2 pollen zone $(245-215 \mathrm{~cm}, \mathrm{C}$. 7870-7820 yr BP; c. 8810-8740 cal yr BP) (Figure 3). This pollen zone also suggests the presence of scattered pockets of Acer, Fraxinus excelsior-type, Alnus and Tilia. Climatic reconstruction estimates an increase of precipitation (150-200 mm), a decrease of seasonality ( $\Delta S$ (summer-winter) $=5^{\circ} \mathrm{C}$ ) and a slight cooling in summer by $4^{\circ} \mathrm{C}$ (Figure 4).

In several French continental sequences such as those from the Pyrenees and the Massif Central, the first occurrence of Tilia has been recorded later, at the beginning of the Atlantic period (7500-5000 yr BP; c. 8320-5730 cal yr BP) (Reille, 1990a; de Beaulieu et al., 1984). However, other sequences such as that of the Soucarat in the Eastern Pyrenees records the appearance of Tilia earlier, at around $7740 \pm 180 \mathrm{yr} B P$ (8575 cal yr BP) (Reille and Andrieu, 1994). Tilia has been also detected earlier (before $7800 \mathrm{yr}$ BP; 8700 cal yr BP) in several central-European pollen sequences such as Soppensee and Bibersee (Switzerland), Schleinsee (Germany) (Tinner and Lotter, 2001; 2006) and in northern European sequences such as those of Raigastvere, Viitna, Rõuge, Ruila (Estonia) (Seppä and Poska, 2004; Veski et al., 2004). 
The next pollen zone, VK03-58Bis-3 (215-151 cm, c. 7820-7530 yr BP; c. 8740-8390 cal yr BP) reflects the maximum expansion of Corylus associated with the contraction of the deciduous Quercus forest. This suggests an important increase of seasonality between 8700 and $8200 \mathrm{cal} \mathrm{yr} \mathrm{BP}$ that is supported by climate estimates (Figure 3 and 4 ).

In recent decades, several hypotheses have been proposed for explaining the rapid expansion of Corylus in Europe during the early Holocene. These hypotheses have included: forest succession and soil development, different rates of spread and physical barriers causing migrational lags, the geographical position of glacial refugia, late glacial expansion, woodland management by Mesolithic immigrants and finally, climate conditions. Huntley (1993) has reviewed these hypotheses suggesting that the early Holocene Corylus expansion was most likely the result of climate conditions, supporting our interpretation. Furthermore it is widely known that Corylus competed against deciduous Quercus trees mostly during the early Holocene in southern Europe (Tallantire, 2002). Corylus is a light-demanding tree and its expansion is favoured by forest openings (Bradshaw and Hannon, 2004). In addition, Corylus is considered to be one tolerant climate species supporting high seasonality conditions (Tallantire, 2002). In French continental sequences, the maximum expansion of Corylus has been also documented at around the same period (9000-8000 yr BP; c. 10190-8870 cal yr BP) (de Beaulieu et al., 1984; Reille and Andrieu, 1991; Reille and Lowe, 1993). Nevertheless, other Pyrenean sequences (de Beaulieu et al., 1984; Reille and Andrieu, 1991; 1995; Reille, 1990b; Reille and Lowe, 1993) provide evidence for a longer period of Corylus optimum extent. VK03-58Bis-3 pollen zone also records a Pinus forest re-expansion. Betula and Ulmus are consistently present and there are sporadic occurrences of Alnus, Fraxinus excelsior-type and Tilia. Occurrences of Fagus at c. 8650 and 8450 cal yr BP reflect a slight decrease in seasonality and temperatures within the period of high seasonality that characterises VK03-58Bis-3 pollen zone.

VK03-58Bis-4 pollen zone (151-147 cm, c. 7530-7240 yr BP; c. 8390-8060 cal yr BP) is marked by a drastic reduction of Corylus woodlands and an increase of Pinus forest along with the maintaining of deciduous Quercus forest (Figure 3). Climate estimates show that the onset of seasonality decrease coincides with the Corylus minimum extent at around c. $7430 \mathrm{yr}$ BP (c. $8270 \mathrm{cal}$ yr BP) (Figure 4). This episode of Corylus decline has been also observed in several central-European (Soppensee and Bibersee in Switzerland and Schleinsee in Germany; Tinner and Lotter, 2001; 2006) and northern European pollen sequences (Raigastvere, Viitna, Rõuge, Ruila in Estonia and Lake Flarken in Sweden (Seppä and Poska, 2004; Veski et al., 2004; Seppä et al., 2005). Corylus deflection has been interpreted as the vegetation response to the well known 8.2 ka cooling event.

Deciduous Quercus forest attained its maximum expansion in the following period (VK03-58Bis-5 pollen zone, 147-102 cm, c. 7240-3290 yr BP; c. 8060-3620 cal yr BP) suggesting a change in climate to milder (reduced seasonality) conditions as the result of MTCO increase (Figures 3 and 4). These conditions, together with an increase of precipitation, favoured the establishment of Alnus, Ulmus, Tilia, Fraxinus excelsior-type and Fagus trees in western France.

The next zone, VK03-58Bis-6 (102-55 cm, c. 3290-1750 yr BP; c. 3620-1950 cal yr BP), indicates the slight contraction of deciduous Quercus forest, the expansion of Fagus and the gradual increase of herbaceous plants. The slight decrease of MTWA and the increase of MTCO lead to this vegetation dynamic in which the Fagus spread has been probably favoured by weak seasonality and high precipitation (Figure 4).

In almost all the continental French sequences, Fagus spread occurred between $4500-4000$ and 2000 years BP (5000-4400 and $2150 \mathrm{cal}$ yr BP) coinciding with the beginning of the oak forest decline (Reille and Lowe, 1993; Reille and Andrieu, 1995; Reille et al., 2000). In our "VK03-58Bis" pollen record, the first occurrence of Fagus is recorded at around 8650 and 8450 cal yr BP. Several occurrences were detected during and after the Corylus regression episode. The beginning of a continuous presence of Fagus occurred at around $4350 \mathrm{yr}$ BP (c. $4810 \mathrm{cal}$ yr BP) just after the Corylus regression although its maximum expansion started later (c. 3290 yr BP; c. 3620 cal yr BP). Tinner and Lotter (2001; 2006) based on pollen analysis from Soppensee and Bibersee (Switzerland) and Schleinsee (Germany) suggest, as with our sequence, that Fagus expands after the episode of Corylus deflection, favoured by more humid summer conditions and less extreme seasonality.

VK03-58Bis-7 pollen zone (55-24 cm, c. $1750-730 \mathrm{yr}$ BP; c. 1950-850 cal yr BP) still shows the gradual reduction of deciduous Quercus forest and the maximum expansion of Poaceae. Fagus is still present in this pollen zone until c. $1060 \mathrm{yr}$ BP (c. $1210 \mathrm{cal}$ yr BP) (Figure 3). The continuous presence of Cerealia type, Juglans and Castanea testifies to agricultural practices at around 2000 years ago in western France. In the last pollen zone, VK03-58Bis-8 (upper $24 \mathrm{~cm}$, last c. $730 \mathrm{yr} \mathrm{BP;} \mathrm{c.} 850 \mathrm{cal}$ yr BP) there is a strong 
increase of Pinus, heathlands and herbaceous plants, mainly Taraxacum and Cyperaceae. Deciduous Quercus forest decrease and Fagus virtually disappears from this region. Climate estimates for the last two pollen zones are complex, reflecting a huge increase of the annual temperature in particular over the last millennia.

\subsection{Climate variability in north-western France}

\subsubsection{Long-term cooling pattern and the Holocene thermal maximum}

Vegetation changes and pollen-based quantitative climate estimates permit the detection of a smallamplitude long-term pattern of summer temperature decrease between 8850 and $2000 \mathrm{yr}$ cal BP.

The long-term cooling is marked by a general trend of temperate and humid tree decline and by the increase of herbaceous plants. This long-term cooling is characterised by the gradual decrease in the MTWA (mean temperature of the warmest month) values (from $20.5^{\circ}$ to $17.5^{\circ} \mathrm{C}$ ) (Figures 5 and 3 ) coinciding with the general trend of mid-latitude summer insolation reduction until at least $2000 \mathrm{cal}$ yr BP (Figure 5). Temperate forest reduction in parallel with a high-latitude summer insolation decrease is recorded by several marine pollen sequences from the Iberian margin during previous interglacial periods such as the Marine Isotopic Stages (MIS) 5, 7, 9 and 11 (Desprat et al., 2005; 2006; 2007; Sánchez Goñi et al., 2005).

Furthermore, temperate and humid forest decrease during the Holocene also mimics the general decreasing trend observed in the $\delta^{18} \mathrm{O}$-isotope composition of the NorthGRIP ice-core (Johnsen et al., 2001) (Figure 5).

The continuous decrease of seasonality follows the gradual increase of the precessional signal. Nonetheless the weak values in precession between 8855 and $8000 \mathrm{cal}$ yr BP surprisingly coincides with an interval of particularly high seasonality suggesting that other mechanisms have probably amplified this precessional signal (see below).

This suggests that long-term vegetation changes in the north-western France seem to respond directly to the Holocene orbital induced climatic variability on which human impact on vegetation was superimposed since at least $2000 \mathrm{cal}$ yr BP.

Studies on continental sequences from the Loire basin suggest that human impact in this region started during the end of the Mesolithic/beginning of the Neolithic (Visset el al., 2002). However, the trends of forest destruction by humans seem to have been different in character, i.e. highly episodic.

These results are in agreement with the previous suggestion that forest recession through the Holocene might be mainly the result of natural processes (Magri, 1995).

Previous studies of sea surface conditions of the North Atlantic and Mediterranean regions have shown an apparent long-term cooling trend that was driven by northern high latitudes summer insolation decreases during the Holocene (Marchal et al., 2002; Andersen et al., 2004; Moros et al., 2004). Several climate models also suggest an orbitally-induced mechanism as the main forcing factor for the long-term climatic trend over the Holocene (Kutzbach and Gallimore, 1988; Crucifix et al., 2002; Weber and Oerlemans, 2003; Renssen et al., 2005). Other authors (Lorenz et al., 2006), have compared global alkenone-derived sea-surface temperature (SST) data with transient climate simulations using a coupled atmosphere-ocean general circulation model (AOGMC) for the last $7000 \mathrm{yr}$ cal BP (less instable climate period) suggesting that mid- to late Holocene long-term SST trends were driven by insolation changes.

The general cooling trend of the Holocene starts generally during or after the well known Holocene thermal maximum (HTM). However, the Holocene warming that defines the HTM occurred on different times depending of places (Kaufman et al., 2004). Several studies on both North-Atlantic marine and Greenland ice cores detect the HTM period at the beginning of the Holocene (Andrews and Giraudeau, 2002; Marchal et al., 2002; Duplessy et al., 2001; Kaufman et al., 2004; Knudsen et al., 2004; de Vernal et al., 2005) while others point to a later climatic optimum (Dahl-Jensen et al., 1998; Bauch et al., 2001; Johnsen et al., 2001; Levac et al., 2001; Kaplan et al., 2002; Solignac et al., 2004; Kaufman et al., 2004; Keigwin et al., 2005).

Unfortunately "VK03-58Bis" shelf core does not cover the entire Holocene record. However, MTWA values were higher between 8855 and $8000 \mathrm{cal} \mathrm{yr} \mathrm{BP}$ than between 8000 and $1000 \mathrm{cal}$ yr BP contrasting with the MTCO (mean temperature of the coldest month) trends which show lower values during the late earlyHolocene than during the mid- and late-Holocene (Figures 4 and 5). 
This strong seasonal contrast between 8855 and 8000 cal yr BP likely favoured the development of Corylus woodlands at the expense of deciduous Quercus forest although MTWA values were high. Mild (lower seasonality) conditions which allowed the expansion of deciduous Quercus forest in north-western France occurred roughly between 8000 and $4000 \mathrm{cal} \mathrm{yr} \mathrm{BP.} \mathrm{This} \mathrm{period} \mathrm{has} \mathrm{been} \mathrm{considered} \mathrm{as} \mathrm{the} \mathrm{HTM}$ in the westernmost part of central Europe because MTWA reconstruction shows higher values than those from present-day (Davis et al., 2003). Other pollen-based climate estimates obtained from several northern European pollen sequences such as Lake Raigastvere, Lake Viitna, Lake Ruila in Estonia and Lake Flarken in Sweden (Seppä and Poska, 2004; Seppä et al., 2005) show higher TANN (mean annual temperatures) values than present-day between 8000 and $4500 \mathrm{cal}$ yr BP, reflecting the HTM in those regions. In contrast, our climate estimates do not detect either higher MTWA or TANN than present day values but reduced seasonality between 8000 and $4500 \mathrm{cal}$ yr BP. Furthermore, the continuous presence of Fagus within this period also suggests (Tinner and Lotter, 2001), besides a weak seasonality, cooler summers and moist conditions. Interestingly, the middle latitudes of western Europe were not submitted to particularly high temperatures between 8000 and $4500 \mathrm{cal}$ yr BP, precluding the identification of the HTM in this region during the last $8850 \mathrm{cal}$ yr BP.

\subsubsection{Sub-orbital climate variability}

Superimposed onto the orbitally induced long-term cooling pattern, pollen analysis and quantitative climate reconstructions from the "VK03-58Bis" shelf core detect sub-orbital climatic variability during the last $8850 \mathrm{cal} \mathrm{yr} \mathrm{BP} \mathrm{(Figure} \mathrm{6).}$

\subsubsection{The multi-centennial-scale climate cooling and the 8.2 ka event}

The maximum expansion and subsequent decline of Corylus woodlands (between c. 8740-8060 cal yr BP), associated with a high seasonality episode in north-western France, occurred synchronously with the following event succession: the last stages of the Laurentide Ice sheet decay, the catastrophic final drainage episodes of the "glacial lakes Agassiz-Ojibway" (Clarke et al., 2004) into the Hudson Bay, at around $8470 \mathrm{cal}$ yr BP (error range of $8160-8740 \mathrm{cal}$ yr BP; Barber et al., 1999), and the consequent 8.2 kyr event (Teller et al., 2002; Clarke et al., 2004). The introduction of large amounts of freshwater into the North Atlantic (Alley et al., 1997; Clark et al., 2001) triggers an important decrease of sea surface temperatures (SST) earlier than the recorded isotopic signal of the $8.2 \mathrm{kyr}$ event in the Greenland ice cores and lasting several centuries, between $\sim 8900$ to 8000 cal yr BP (Ellison et al., 2006). This multicentennial SST cooling detected by the high resolution North Atlantic deep-sea core MD99-2251 (Figure 1) occurred roughly contemporaneously with the climate cooling defined by Rohling and Pälike (2005) ( $\sim 8600$ and $8000 \mathrm{cal}$ yr BP) (Ellison et al., 2006). SST cooling ( 8600 and $8000 \mathrm{cal} \mathrm{yr} \mathrm{BP)} \mathrm{has} \mathrm{also} \mathrm{been}$ observed in other regions of the North Atlantic such as over the Laurentian Fan (Keigwin et al., 2005) and in the north of Iceland (Knudsen et al., 2004).

The cooling and freshening of the surface ocean, that started at around 400-500 yr before the drastic 8.2 kyr event, is linked with the beginning of a long and gradual pattern of reduction in the flow speed of Iceland-Scotland Overflow water (ISOW), a component of the NADW, which attains the slowest flow speed at around $8290 \mathrm{yr}$ cal BP and lasted $200 \mathrm{yr}$, concomitant with the $8.2 \mathrm{kyr}$ event (Ellison et al., 2006). The introduction of large amounts of freshwater favoured the reduction of the North Atlantic Deep Water (NADW) formation (Clark et al., 2001) and the consequent weakening of the conveyor belt (Barber et al., 1999; Rahmstorf, 2002; Renssen et al., 2001). This mechanism has a great impact on the spread of winter sea-ice in the North Atlantic region playing an important role on seasonality increase (Denton et al., 2005).

We propose that the amplified signal of seasonality in north-western France has been driven by the final episodes of Agassiz and Ojibway outbursts, through the winter sea-ice expansion in the high latitudes of the North Atlantic region triggering the beginning of the maximum spread of Corylus woodlands ( at around c. $8740 \mathrm{cal} \mathrm{yr} \mathrm{BP).}$ 
The maximum Corylus woodland (c. $8740-8390 \mathrm{cal}$ yr BP) expansion, related to colder winters, is almost synchronous with the T. communis level (c.8740-8490 cal yr BP) in "VK03-58Bis" shelf core (Figure 3) but also with its decline (c. 8480 and c. 8390 cal yr BP). T. communis can occur locally in the fine sandy beds of the south-western French shelf (Glemarec, 1969) although it is commonly found nowadays in the Boreal marine biogeographical zone of the north Atlantic region, between 50 and $68^{\circ} \mathrm{N}$ (Figure 7) (Funder et al., 2002). It is known that during the warmest phases of the early Eemian the boreal marine zone migrated further north through the Barents and Kara sea to the Taymyr (Funder et al., 2002). On the contrary during the early Holocene and, in particular, between c. 8740-8480 cal yr BP (i.e. T. communis level), when the north Atlantic sea-ice cover most likely extended further south as the result of the decrease in winter temperatures, this Boreal biogeographical zone was probably deflected several degrees further south allowing the settlement of T. communis off north-western France.

Between c. 8480 and c. $8390 \mathrm{cal}$ yr BP a drastic environmental change triggered the T. communis death and the decrease of the dinocyst Lingulodinium machaerophorum (Figure 3). This change can not be due

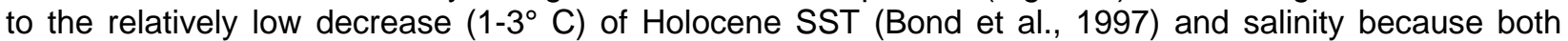
species tolerate great amplitude changes (Funder et al., 2002; Turon, 1984; Lewis and Hallet, 1997). One regional event such as the opening of the English Channel (Figure 1) (9000-7500 cal yr BP, Lambeck, 1997; 8500-8400 cal yr BP, Jiang et al., 1997; 8600-8500 cal yr BP, Gyllencreutz and Kissel, 2006) could be the main trigger for $\mathrm{T}$. communis mortality and Lingulodinium machaerophorum decline. Indeed the opening of the English Channel contributed to a drastic hydrological, sedimentological as well as biological change in the north-western France (Bourillet et al., 2005) which probably affected the benthic and planktic communities.

The $8.2 \mathrm{kyr}$ event is marked in north-western France by the drastic episode of Corylus forest decline (c. 8390-8060 cal yr BP) (Figure 6) as already observed in central and northern Europe (Tinner and Lotter, 2001, 2006; Seppä and Poska, 2004; Veski et al., 2004; Seppä et al., 2005). Contemporaneously with the Corylus forest decline, decreases in PANN and MTCO (of about $100 \mathrm{~mm}, 2^{\circ} \mathrm{C}$ ) are observed and seasonality remains high in north-western France (Figure 6). A modelling-data comparison (Wiersma and Renssen, 2005) and pollen-based quantitative climate estimates from Europe (Davis et al., 2003) also show a temperature reduction of at least $1^{\circ} \mathrm{C}$.

The drastic MOC (Meridional Overturning Circulation) reduction at $8.2 \mathrm{kyr} \mathrm{BP}$, associated with the slowest flow of the ISOW (Iceland-Scotland Overflow Water) (Ellison et al., 2006), has probably amplified the signal of the Greenland isotopic record contributing to the European temperature decrease which favoured the decline of the Corylus trees not only in north-western France but also in Central and Northern Europe. Following the $8.2 \mathrm{kyr}$ event, the decrease of seasonality favours the deciduous Quercus expansion at the expense of Corylus woodlands.

Furthermore, our data suggests a complex pattern of annual precipitation in north-western France during the multi-centennial cooling that encompasses the $8.2 \mathrm{kyr}$ event (Figures 4 and 6). High annual precipitations characterise the beginning and the end phases of this cooling episode bracketing a drier period. Lake level changes in Lake Annecy reveal the same complex pattern around the $8.2 \mathrm{kyr}$ event with two high levels separated by a low one (Magny et al., 2003). Furthermore, these high lake levels, interpreted by the authors as two episodes of high precipitation, are associated with relatively low MTWA values (Magny et al., 2003; Magny and Bégeot, 2004).

\subsubsection{Other possible millennial-scale cooling episodes}

After the final episodes of the Agassiz and Ojibway outburst flooding climate became more stable and therefore millennial-scale climatic events are less evident during the mid- and late- Holocene. Quantitative climate estimates from "VK03-58Bis" show several small amplitude millennial-scale cooling episodes between the $8.2 \mathrm{kyr}$ event and $2000 \mathrm{yr}$ cal BP (Figure 6). The climate variability over the last $2000 \mathrm{yr}$ is probably masked by human impact.

Cooling events are marked in most cases by an increase of precipitation values and seasonality as well as by a slight decrease of MTCO values. Because we only have two radiocarbon-dated levels for the last 8000 years it is difficult to correlate our events with other well dated and worldwide cooling episodes (Mayewski et al., 2004). Nonetheless, these events may be linked with the SST coolings detected in the North Atlantic (Bond et al., 1997; 2001) and with some of the ten high lake levels identified in several mid- 
European lacustrine records that occurred after the $8.2 \mathrm{kyr}$ event (Magny, 2004). However further research is needed to investigate this linkage.

\section{Conclusions}

High resolution pollen analysis and quantitative climate reconstruction from "VK03-58Bis" shelf core allow the detection of a small-amplitude long-term cooling pattern as well as millennial-scale climate variability over the last 8850 years in north-western France:

- Both the gradual decrease of temperate and humid trees and MTWA (mean temperature of the warmest month) values follow the general trend of northern mid-latitude summer insolation reduction until at least $2000 \mathrm{cal}$ yr BP. The general trend of seasonality decrease follows the gradual increase of the precession index;

- The high seasonality conditions of north-western France (between c. 8740-8060 cal yr BP) was concomitant with the multi-centennial-scale climate cooling encompassing the $8.2 \mathrm{kyr}$ event. Orbitally induced colder winters were probably amplified by the increase of winter sea-ice cover in the high latitudes of the north Atlantic as the result of the final episodes of Agassiz and Ojibway outbursts and consequent gradual reduction of the MOC (Meridional Overturning Circulation). This increase of seasonality favoured the spread of Corylus woodlands at the expense of the deciduous Quercus forest between c. 8740-8390 cal yr BP.

- Superimposed on the multi-centennial-scale climate event an extreme winter cooling triggered the Corylus tree decline (c. 8390-8060 cal yr BP) in north-western France and has been identified and related to the short-lived $8.2 \mathrm{kyr}$ cooling event. Although seasonality remains important, winter temperature over Europe and Greenland dropped due to the final drastic MOC reduction associated with slowest flow of the ISOW (Iceland-Scotland Overflow Water);

- We have detected a complex pattern in annual precipitation within the multi-centennial-scale cooling (between c. 8740-8060 cal yr BP): a relatively dry period in north-western France was sandwiched by two episodes of increased moisture availability;

- our study also suggests several small amplitude millennial-scale cooling events after the $8.2 \mathrm{kyr}$ event marked by an increase of PANN and seasonality as well as by a slight decrease of MTCO (mean temperature of the coldest month) values.

Finally, the high abundance of the marine mollusc T. communis between c. $8740-8480 \mathrm{cal}$ yr BP points to the migration of the Boreal biogeographical zone several degrees further south, during the first part of the multi-centennial cooling episode. T. communis death and the decrease of the Lingulodinium machaerophorum dinocyst, between c. 8480 and c. $8390 \mathrm{cal} \mathrm{yr} \mathrm{BP,} \mathrm{was} \mathrm{most} \mathrm{probably} \mathrm{triggered} \mathrm{by} \mathrm{the}$ opening of the English Channel.

\section{Acknowledgements}

This study has been supported by the IFREMER research project "Défi Golfe de Gascogne". The authors would like to thank Pascal Le Roy chief scientist and his crew of the R/V "Côtes de la Manche" for their efficient work during the Vibarmor cruise and to William Fletcher for the English revision which greatly improved this manuscript. Authors also like to thank Marie Helene Castera for palynological treatments. Finally, we are grateful to Michel Magny and to an anonymous referee for their constructive criticisms which greatly improve this paper.

This paper is Bordeaux 1 University, UMR-CNRS 5805 EPOC contribution n 1655. 


\section{References}

Allen, G.P. and Castaing, P. 1977: Carte de répartition des sédiments superficiels sur le plateau continental du Golfe de Gascogne. Bulletin de I'Institut de Géologie du Bassin d'Aquitaine. Talence France, 255-260.

Alley, R.B and Ágústsdóttir, A.M. 2005: The 8 k event: cause and consequences of a major Holocene abrupt climate change. Quaternary Science Reviews 24, 1123-1149.

Alley, R.B., Mayewski, P.A., Sowers, T., Stuiver, M., Taylor, K.C. and Clark, P.U. 1997: Holocene climatic instability: a prominent widespread event 8200 years ago. Geology 25, 483-486.

Alley, R.B., Marotzke, J., Nordhaus, W.D., Overpeck, J.T., Peteet, D.M., Pielke, R.A., Pierrehumbert, R.T.Jr., Rhines, P.B., Stocker, T.F., Talley, L.D. and Wallace, J.M. 2003: Abrupt climate change. Science 299, 2005-2010.

Andersen, A., Koç, N., Jennings, A., and Andrews, J.T. 2004: Nonuniform response of the major surface currents in the Nordic Seas to Insolation forcing: implications for the Holocene climate variability. Paleoceanography 19, 2003, DOI: 10.1029/2002PA000873.

Andrews, J.T. and Giraudeau, J. 2002: Multi-proxy records showing Holocene oceanographic variability: the inner N. Iceland Shelf (Húnaflói). Quaternary Science Reviews 22, 175-193.

Baldini, J.U.L., McDermott, F. and Fairchild, I.J. 2002: Structure of the 8200-year cold event revealed by a speleothem trace element record. Science 296, 2203-2206.

Barber, K.E., Chambers, F.M., Maddy, D., Stoneman, R.E. and Brew, J.S. 1994: A sensitive high resolution record of Late Holocene climatic change from a raised bog in Northern England. The Holocene 4, 198-205.

Barber, D.C., Dyke, A., Hillaire-Marcel, C., Jennings, A.E., Andrews, J.T., Kerwin, M.W., Bilodeau, G., McNeely, R., Southon, J., Morehead, M.D. and Gagnon, J.-M. 1999: Forcing of the cold event of 8,200 years ago by catastrophic drainage of Laurentide lakes. Nature 400, 344- 348.

Bauch, H.A., Erlenkeuser, H., Spielhagen, R.F., Struck, U., Matthiessen, J., Thiede, J. and Heinemeier, J. 2001: A multi-proxy reconstruction of the evolution of deep and surface waters in the subartic Nordic Seas over the last 30,000 yr. Quaternary Science Reviews 20, 659-678.

Berger A. 1978: Long-term variations of daily insolation and Quaternary climatic changes. Journal of the Atmospheric Sciences 35, 2362-2367.

Bianchi, G. G. and McCave. I. N. 1999: Holocene periodicity in North Atlantic climate and deep-ocean flow South of Iceland. Nature 397, 515-17.

Bond, G., Showers, W., Cheseby, M., Lotti, R., Almasi, P., deMenocal, P., Priore, P., Cullen, H., Hajdas, I. and Bonani, G. 1997: A pervasive millennial-scale cycle in North Atlantic Holocene and glacial climates. Science 278, 1257- 1266.

Bond, G., Kromer, B., Beer, J., Muscheler, R., Evans, M., Showers, W., Hoffmann, S., Lotti-Bond, R., Hajdas, I. and Bonani, G. 2001: Persistent solar influence on North Atlantic climate during the Holocene. Science 294, 2130-2136.

Bottema, S. and van Straaten, L.M.J.U. 1966: Malacology and palynology of two cores from the Adriatic sea floor. Marine Geology 4, 553-564. 
Bourillet, J-F., Loubrieu, B., Levron, L., Apprioual, R. and Weber, O. 2002: Reconnaissance sédimentologique du nord de la Grande Vasière: résultats préliminaires de la mission Trophal 1. In Ifremer Ed Colloque du Défi Golfe de Gascogne. Ifremer, Brest, 11-.13 December 2002.

Bourillet, J-F., Dubrulle, C., Goubert E., Jouanneau, J.-M., Cortijo, E., Weber, O., Lesueur, P. and Vicaire, O. 2005: La Grande Vasière : architecture, mise en place et estimation des facteurs de son évolution. In Ifremer Ed Colloque Défi Golfe de Gascogne. Ifremer, Brest, 22-24 March 2005.

Bourillet, J-F., Jouanneau, J-M., Macher, C., Le Hir, P. and Naughton, F. 2006: "La Grande Vasière" midshelf mud belt: Holocene sedimentary structure, natural and anthropogenic impacts, $X$ International Symposium on Oceanography of the Bay of Biscay, Vigo, Spain, April 19-21 2006, 131-134.

Bradshaw, R.H.W and Hannon, G.E. 2004: The Holocene structure of North-west European temperate forest induced from palaeoecological data. In O. Honnay, K. Verheyen, B. Bossuyt and M. Hermy Ed; Forest biodiversity: Lessons from History for conservation, 11-25.

Castaing, P. and Jouanneau, J.-M. 1987: Les apports sédimentaires actuels d'origine continentale aux océans. Bulletin de l'Institut Géologique du Bassin d'Aquitaine 41, 53-65.

Clark, P.U., Marshall, S.J., Clarke, G.K.C., Hostetler, S.W., Licciardi, J.M. and Teller, J.T. 2001: Freshwater forcing of abrupt climate change during the last glaciation. Science 293, 283-287.

Clarke, G.K.C., Leverington, D.W., Teller, J.T. and Dyke, A.S. 2004: Paleohydraulics of the last outburst flood from glacial Lake Agassiz and the 8200 BP cold event. Quaternary Science Reviews 23, 389-407.

Crucifix, M., Loutre, M.-F., Tulkens, P., Fichefet, T. and Berger, A. 2002: Climate evolution during the Holocene: a study with an Earth system model of intermediate complexity. Climate Dynamics 19, 43-60.

Dahl-Jensen, D., Monsegaard, K., Gundestrup, N., Clow, G.D., Johnsen, S.J., Hansen, A.W. and Balling, N. 1998: Past temperatures directly from the Greenland ice sheet. Science 282, 268-271.

Davis, B.A.S., Brewer, S., Stevenson, A.C., Guiot J. and Data Contributors. 2003: The temperature of Europe during the Holocene reconstructed from pollen data. Quaternary Science Reviews 22, 1701-1716.

de Beaulieu, J.-L., Pons, A., Reille, M. 1984: Histoire de la végétation, du climat et de l'action de l'homme dans le Massif Central français depuis 15.000 ans. Institut français de Pondichéry, 30, 27-32.

de Vernal, A., Henry, M. and Bilodeau, G. 1996: Techniques de préparation et d'analyse en micropaléontologie. In Les cahiers du GEOTOP, Département des Sciences de la terre. Québec University, Montréal, 3, 16-27.

de Vernal, A., Hillaire-Marcel, C. and Darby, D.A. 2005: Variability of sea-ice cover in the Chukchi Sea (western Arctic Ocean) during the Holocene. Paleoceanography, 20, 4018, DOI:

10.1029/2005PA001157.

de Vernal, A., Rochon, A., Turon, J.-L. and Matthiessen, J. 1998: Organic-walled dinoflagellate cysts: palynological tracers of sea surface conditions in middle to high latitude marine environments. Geobios 30, 905-920.

Denton, G.H. and Karlén, W. 1973: Holocene climatic variations: their pattern and possible cause. Quaternary Research 3, 155- 205.

Denton, G.H., Alley, R.B., Comer, G.C. and Broecker, W.S., 2005: The role of seasonality in abrupt climate change. Quaternary Science Reviews 24, 1159-1182. 
Desprat, S., 2005: Réponses climatiques marines et continentales du Sud-Ouest de l'Europe lors des derniers interglaciaires et des entrées en glaciations. PhD Thesis, Bordeaux University, France, 282 pp.

Desprat S., Sánchez Goñi M.F., Naughton, F., Turon J.-L., Duprat J., Malaizé B. and Peypouquet J.-P. 2007. Climate variability of the last five isotopic interglacials from direct land-sea-ice correlation, In: Sirocko, F., Litt, T., Claussen, M., Sánchez Goñi, M.F. (eds.), Climate of Past Interglacials.

Desprat, S., Sánchez Goñi, M.F., Turon, J.-L., McManus, J.F., Loutre, M.F., Duprat, J., Malaizé, B., Peyron, O. and Peypouquet, J.-P. 2005: Is vegetation responsible for glacial inception during periods of muted insolation changes? Quaternary Science Reviews 24, 1361-1374.

Desprat, S., Sánchez Goñi, M.F., Turon, J.-L., Duprat, J., Malaizé, B. and Peypouquet, J.-P., 2006: Climatic variability of Marine Isotope Stage 7: direct land-sea-ice correlation from a multiproxy analysis of a northwestern Iberian margin deep-sea core. Quaternary Science Reviews 25, 1010-1026.

Duplessy, J.C., Ivanova, E., Murdmaa, I., Paterne, M. and Labeyrie, L. 2001: Holocene paleoceanography of the northern Barents Sea and variations of the northward heat transport by the Atlantic Ocean. Boreas $30,2-16$.

Ellison, C.R.W., Chapman, M.R. and Hall, I.R. 2006: Surface and deep ocean interactions during the cold climate event 8200 years ago. Science 312, 1929-1932.

Folliot, B. 2004: La Grande Vasière : Etude sédimentologique de deux secteurs septentrionaux. DEA on Dynamique et Environnements Sédimentaires Lille-Caen-Rouen, France, 39pp.

Funder, S., Demidov, I. and Yelovicheva, Y. 2002: Hydrography and mollusc faunas of the Baltic and the White Sea-North Sea seaway in the Eemian. Palaeogeography, Palaeoclimatology, Palaeoecology 184, 275-304.

Glemarec, M. 1969: Les peuplements benthiques du plateau continental nord-Gascogne. PhD Thesis, Paris University, France, 167 pp.

Groot, J.J. and Groot, C.R. 1966: Marine palynology: possibilities, limitations, problems. Marine Geology 4, 387-395.

Guiot, J. 1990: Methodology of the last climatic reconstruction in France from pollen data. Palaeogeography, Palaeoclimatology, Palaeoecology 80, 49-69.

Guiot, J., Pons, A., de Beaulieu, J.L. and Reille, M. 1989: A 140 000-year continental climate reconstruction from two European pollen records. Nature 338, 309-313.

Gyllencreutz, R. and Kissel, C. 2006: Late Glacial and Holocene sediment sources and transport patterns in the Skagerrak interpreted from mineral magnetic properties and grain size data. Quaternary Science Reviews 25, 1247-1263.

Heusser, L.E. and Balsam, W.L. 1977: Pollen distribution in the N.E. Pacific ocean. Quaternary Research 7, 45-62.

Heusser, L.E. and Stock, C.E. 1984: Preparation techniques for concentrating pollen from marine sediments and other sediments with low pollen density. Palynology 8, 225-227.

Hughen, K.A., Baillie, M.G.L., Bard, E., Bayliss, A., Beck, J.W., Bertrand, C., Blackwell, P.G., Buck, C.E., Burr, G., Cutler, K.B., Damon, P.E., Edwards, R.L., Fairbanks, R.G., Friedrich, M., Guilderson, T.P., Kromer, B., McCormac, F.G., Manning, S., Bronk Ramsey, C., Reimer, P.J., Reimer, R.W., Remmele, S., Southon, J.R., Stuiver, M., Talamo, S., Taylor, F.W., van der Plicht, J. and Weyhenmeyer, C.E. 2004: Marine04 Marine Radiocarbon Age Calibration, 0-26 Cal Kyr BP. Radiocarbon 46, 1059-1086. 
Hughes, P.D.M., Mauquoy, D., Barber, K.E. and Langdon, P.G. 2000: Mire development pathways and palaeoclimatic records from a full Holocene peat archive at Walton Moss, Cumbria, England. The Holocene 10, 465-479.

Hughes, P.D.M., Blundell, A., Charman, D.J., Barlett, S., Daniell, J.R.G., Wojatschke, A. and Chambers, F.M. 2006: An 8500cal. Year multi-proxy climate record from a bog in eastern Newfoundland: contributions of meltwater discharge and solar forcing. Quaternary Science Reviews 25, 1208-1227.

Huntley, B. 1993: Rapid early Holocene migration and high abundance of hazel (Corylus avellana L.): alternative hypotheses. In Chambers, F.M. Ed. Climate change and human impact on the landscape, Chapman \& Hall, London, PA, 205-215.

Jiang, H., Björck, S. and Knudsen, K.L. 1997: A palaeoclimatic and palaeoceanographic record of the last $11000{ }^{14} \mathrm{C}$ years from the Skagerrak-Kattegat, northeastern Atlantic margin. The Holocene 7, 301-310.

Johnsen, S.J., Dahl-Jensen, D., Gundestrup, N., Steffensen, J.P., Clausen, H.B., Miller, H., MassonDelmotte, V., Sveinbjornsdottir, A.E. and White, J. 2001: Oxygen isotope and palaeotemperature records from six Greenland ice-core stations: Camp Century, Dye- 3, GRIP, GISP2, Renland and NorthGRIP. Journal of Quaternary Science 16, 299-307.

Jouanneau, J.M., Weber, O., Cremer, M. and Castaing, P. 1999: Fine-grained sediment budget on the continental margin of the Bay of Biscay. Deep-Sea Research II 46, 2205-2220.

Kaplan, M., Wolfe, A. and Miller, G. 2002: Holocene environmental variability in southern Greenland inferred from lake sediments. Quaternary Research 58, 149-159.

Kaufman, D.S., Ager, T.A., Anderson, N.J., Anderson, P.M., Andrews, J.T., Bartlein, P.J., Brubaker, L.B., Coats, L.L., Cwynar, L.C., Duvall., M.L., Dyke, A.S., Edwards, M.E., Eisner, W.R., Gejewski, K., Geirsdóttir, A., Hu, F.S., Jennings, A.E., Kaplan, M.R., Kerwin, M.W., Lozhkin, A.V., MacDonald, G.M., Miller, G.H., Mock, C.J., Oswald, W.W., Otto-Bliesner, B.L., Porinchu, D.F., Rühland, K., Smol, J.P., Steig, E.J. and Wolfe, B.B. 2004: Holocene thermal maximum in the Western Arctic (0 to 180W). Quaternary Science Reviews 23, 529-560.

Keigwin, L.D., Sachs, J.P., Rosenthal,Y. and Boyle, E.A. 2005: The 8200 year B.P. event in the slope water system, western subpolar North Atlantic. Palaeoceanography 20, 2003, DOI:10.1029/2004PA00174.

Klitgaard-Kristensen, D., Sejrup, H.P., Haflidason, H., Johnsen, S. and Spurk, M. 1998: A regional 8200 cal yr BP cooling event in northwest Europe, induced by final stages of the Laurentide ice sheet deglaciation? Journal of Quaternary Science 13, 165-169.

Knudsen, K.L., Jiang, H., Jansen, E., Eiriksson, J., Heinemeier, J. and Seidenkrantz, M.S. 2004: Environmental changes off North Iceland during the deglaciation and the Holocene: foraminifera, diatoms and stable isotopes. Marine Micropaleontology 50, 273-305.

Koreneva, E.V. 1966: Marine palynological researches in the U.S.S.R. Marine Geology 4, 565-574.

Kutzbach, J. E. and Gallimore, R. G. 1988: Sensitivity of a coupled atmosphere/mixed layer ocean model to changes in orbital forcing at 9000 years BP. Journal of Geophysical Research 93, 803-821.

Lambeck, K. 1997: Sea-level change along the French Atlantic Channel coasts since the time of the Last Glacial Maximum. Palaeogeography, Palaeoclimatology, Palaeoecology 129, 1-22. 
Lesueur, P., Jouanneau, J-M., Boust, D., Tastet, J-P. and Weber, O. 2001: Sedimentation rates and fluxes in the continental shelf mud fields in the Bay of Biscay (France). Continental Shelf Research 21, 1383-1401.

Lesueur P. and Klingebiel, A. 1976: Carte des sédiments superficiels du plateau continental du Golfe de Gascogne (échelle 1/500 000). BRGM-IFREMER Ed Carte Géologique de la marge continentale française, $23 \mathrm{pp}$.

Levac, E., de Vernal, A. and Blake W.Jr. 2001: Sea-surface conditions in northernmost Baffin Bay during the Holocene: palynological evidence. Journal of Quaternary Science 16, 353-363.

Lewis, J. and Hallett, R., 1997: Lingulodinium polyedrum (Gonyaulax polyedrum), a blooming dinoflagellate. Oceanography and Marine Biology: an Annual Review 35, 97-161.

Langdon, P.G., Barber, K.E. and Hughes, P.D.M. 2003: A 7500-year peat-based paleoclimatic reconstruction and evidence for an 1100-year cyclicity in bog surface wetness from Temple Hill Moss, Pentland Hills, southeast Scotland. Quaternary Science Reviews 22, 259-274.

Lorenz, S. J., Kim, J.-H., Rimbu, N., Schneider, R. R. and Lohmann G. 2006: Orbitally driven insolation forcing on Holocene climate trends: evidence from alkenone data and climate modelling. Paleoceanography 21, 1002, DOI:10.1029/2005PA001152.

Magny, M. 2004: Holocene climate variability as reflected by mid-European lake-level fluctuations, and its probable impact on prehistoric human settlements. Quaternary International 113, 65-79.

Magny, M. and Bégeot, C. 2004: Hydrological changes in the European midlatitudes associated with freshwater outbursts from Lake Agassiz during the Younger Dryas event and the early Holocene. Quaternary Research 61, 181-192.

Magny, M., Bégeot, C., Guiot, J. and Peyron, O. 2003: Contrasting patterns of hydrological changes in Europe in response to Holocene climate cooling phases. Quaternary Science Reviews 22, 1589-1596.

Magri, D. 1995: Some questions on the late-Holocene vegetation of Europe. The Holocene 5, 354-360.

Marchal, O., Cacho, I., Stocker, T.F., Grimalt, J.O., Calvo, E., Martrat, B., Shackleton, N., Vautravers, M., Cortijo, E., van Kreveld, S., Andersson, C., Koç, N., Chapman, M., Sbaffi, L., Duplessy, J.-C., Sarnthein, M., Turon, J.-L., Duprat, J., and Jansen, E. 2002: Apparent long-term cooling of the sea surface in the northeast Atlantic and Mediterranean during the Holocene. Quaternary Science Reviews 21, 455-483.

Mayewski, P.A., Meeker, L.D., Twickler, M.S., Whitlow, S., Yang, Q., Lyons, W.B. and Prentice, M. 1997: Major features and forcing of high-latitude northern hemisphere atmospheric circulation using a 110,000year-long glaciochemical series. Journal of Geophysical Research 102, 26345-26366.

Mayewski, P.A., Rohling, E., Stager, C., Karlén, W., Maasch, K., Meeker, L.D., Meyerson, E., Gasse, F., van Kreveld, S., Holmgren, K., Lee-Thorp, J., Rosqvist, G., Rack, F., Staubwasser, M. and Schneider, R. 2004: Holocene climate variability. Quaternary Research 62, 243-255.

McCave, I.N. 1972: Transport and Escape of Fine-Grained Sediment from Shelf Areas. In Swift, D.J.P., Duane, D.B.and Pilkey, O.H. Eds. Shelf Sediment Transport Process and Pattern, Dowden, Hutchinson and Ross, Inc., Stroudsburg, PA, 225-248.

Migeon, S., Weber, O., Faugeres, J.C. and Saint-Paul, J. 1999: SCOPIX: A new imaging system for core analysis. Geo-Marine Letters 18, 251-255.

Moros, M., Emeis, K., Risebrobakken, B., Snowball, I., Kuipers, A., McManus, J. \& Jansen, E. 2004: Sea surface temperatures and ice rafting in the Holocene North Atlantic: climate influences on northern Europe and Greenland. Quaternary Science Reviews 23, 2113-2126. 
Muller, J. 1959: Palynology of recent Orinoco delta and shelf sediments. Micropaleontology 5, 1-32.

Muscheler, R., Beer, J. and Vonmoos, M. 2004: Causes and timing of the $8200 \mathrm{yr}$ BP event inferred from the comparison of the GRIP ${ }^{10} \mathrm{Be}$ and the tree ring $\Delta^{14} \mathrm{C}$ record. Quaternary Science Reviews 23, 21012111.

Naughton, F., Sánchez Goñi, M.F., Desprat, S., Turon, J-L., Duprat, J., Malaizé, B., Joli, C., Cortijo, E., Drago, T. and Freitas, M.C. 2007: Present-day and past (last 25000 years) marine pollen signal off western Iberia. Marine Micropaleontology 62, 91-114.

Nesje, A. and Dahl, S.O. 2001: The Greenland 8200 cal yr BP event detected in loss-on ignition profiles in Norwegian lacustrine sediment sequences. Journal of Quaternary Science 16, 155-166.

O'Brien, S.R., Mayewski, P.A., Meeker, L.D., Meese, D.A., Twickler, M.S. and Whitlow, S.I. 1995: Complexity of Holocene climate as reconstructed from a Greenland ice core. Science 270, 1962- 1964.

Peck, R.M. 1973: Pollen budget studies in a small Yorkshire catchment. In Birks, H.J.B. and West, R.G. Eds. Quaternary Plant Ecology, The $14^{\text {th }}$ symposium of the British Ecological Society, University of Cambridge, Blackwell Scientific Publications, 43-60.

Peyron, O., Guiot, J., Cheddadi, R., Tarasov, P., Reille, M., de Beaulieu, J.-L., Bottema, S. and Andrieu, V. 1998: Climatic reconstruction in Europe for 18,000 yr BP from Pollen Data. Quaternary Research 49, 183-196.

Peyron, O., Bégeot, C., Brewer, S., Heiri, O., Magny, M., Millet, L., Ruffaldi, P., Van Campo E. and Yu, G. 2005: Late-Glacial climatic changes in Eastern France (Lake Lautrey) from pollen, lake-levels, and chironomids. Quaternary Research 64, 197-211.

Pinot, J-P. 1974: Le précontinent Breton entre Penmarch, Belle Île et l'escarpement continental. Etude géomorphologique. PhD Thesis, Brest University, France, 256 pp.

Pons A. and Reille, M. 1986: Nouvelles recherches pollenanalytiques à Padul (Granada) : La fin du dernier glaciaire et l'Holocene. In E. López-Vera ed. Quaternary climate in Western Mediterranean, University Autónoma de Madrid, 405-420.

Rahmstorf, S. 2002: Ocean circulation and climate during the past 120,000 years. Nature 419, 207-214.

Reille, M. 1990a: Novelles recherches pollenanalytiques dans le bassin de Lourdes (Pyrénées Occidentales, France). Laboratoire de Botanique Historique et Palynologie, Marseille, Unpublished report, December, 1990, 16pp.

Reille, M. 1990b: Novelles recherches pollenanalytiques à Freychinede, Pyrénées ariégeoises, France. Laboratoire de Botanique Historique et Palynologie, Marseille, Unpublished report, November, 1990, $10 \mathrm{pp}$.

Reille, M. and Andrieu, V. 1991: Données nouvelles sur l'histoire postglaciaire de la végétation des Pyrénées occidentales (France). Comptes rendus de l'Académie des sciences, Paris, 312, 97-103.

Reille, M. and Andrieu, V. 1994: Vegetation history and human action in Ariege (Pyrenees, France). Dissertationes Botanicae, 234, 413-422.

Reille, M. and Andrieu, V. 1995: The late Pleistocene and Holocene in the Lourdes basin, western Pyrenees, France: new pollen analytical and chronological data. Vegetation History and Archaeobotany 4, 1-21. 
Reille, M. and Lowe, J.J. 1993: A re-evaluation of the vegetation history of the eastern Pyrenees (France) from the end of the last glacial to the present. Quaternary Science Reviews 12, 47-77.

Reille, M., de Beaulieu, J.L., Svobodova, H., Andrieu-Ponel, V. and Goeury, C. 2000: Pollen analytical biostratigraphy of the last five climatic cycles from a long continental sequence from the Velay region (Massif Central, France). Journal of Quaternary Science 15, 665-685.

Renssen, H., Goosse, H., Fichefet, T. and Campin, J.M. 2001: The 8.2 kyr BP event simulated by a global atmosphere-sea-ice-ocean model. Geophysical Research Letters 28, 1567-1570.

Renssen, H., Goosse, H., Fichefet, T., Brovkin, V., Driesschaert, E., and Wolk, F. 2005: Simulating the Holocene climate evolution at northern high latitudes using a coupled atmosphere-sea ice-oceanvegetation mode. Climate Dynamics 24, 23-43.

Rind, D., Chandler, M., Lerner, J., Martinson, D.G. and Yuan, X. 2001: Climate response to basin-specific changes in latitudinal temperature gradients and implications for sea-ice variability. Journal of Geophysical Research 106, 20161-20173.

Risebrobakken, B., Jansen, E., Andersson, C., Mjelde, E. and Hevroy, K. 2003: A high resolution study of Holocene paleoclimatic and paleoceanographic changes in the Nordic Seas. Paleoceanography 18, 1017, 10.1029/2002PA000764.

Rochon, A., de Vernal, A., Turon, J-L., Matthiessen, J., and Head, M. 1999: Distribution of dinoflagellate cyst assemblages in surface sediments from the North Atlantic Ocean and adjacent

basins and quantitative reconstruction of sea-surface parameters. American Association of Stratigraphic Palynologists, Contribution Series No. 35.

Rohling, E. J. and Pälike H. 2005: Centennial-scale climate cooling with a sudden cold event around 8,200 years ago. Nature 434, 975-979.

Sánchez Goñi, M.F., Loutre, M.F., Crucifix, M., Peyron, O., Santos, L., Duprat, J., Malaizé , B., Turon, J.L. and Peypouquet, J.-P. 2005: Increasing vegetation and climate gradient in western Europe over the Last Glacial Inception (122-110 ka): models-data comparison. Earth and Planetary Science Letters 231, 111-130.

Seppä, H. and Poska, A. 2004: Holocene annual mean temperature changes in Estonia and their relationship to solar insolation and atmospheric circulation patterns. Quaternary Research 61, 22-31.

Seppä, H., Hammarlund, D. and Antonsson, K. 2005: Low-frequency and high-frequency changes of temperature and effective humidity during the Holocene in South central Sweden: Implications for atmospheric and oceanic forcings of climate. Climate Dynamics 25, 285-297.

Solignac, S., de Vernal, A. and Hillaire-Marcel, C. 2004: Holocene sea-surface conditions in the North Atlantic-contrasted trends and regimes in the western and eastern sectors (Labrador Sea vs. Iceland Basin). Quaternary Science Reviews 23, 319-334.

Stuiver, M. and Reimer, P.J. 1993: Extended ${ }^{14} \mathrm{C}$ database and revised CALIB radiocarbon calibration program. Radiocarbon 35, 215-230.

Stuiver, M., Reimer, P.J. and Reimer, R.W. 2005: CALIB 5.0. (WWW program and documentation).

Tallantire, P.A. 2002: The early Holocene spread of hazel (Corylus avellana L.) in Europe north and west of the Alps: an ecological hypothesis. The Holocene 12, 81-96.

Telford, R.J., Heegaard, E. and Birks, H.J.B. 2004: The intercept is a poor estimate of a calibrated radiocarbon age. The Holocene 14, 296-298. 
Teller, J.T., Leverington, D.W. and Mann, J.D. 2002: Freshwater outbursts to the oceans from glacial Lake Agassiz and their role in climate change during the last deglaciation. Quaternary Science Reviews 21, 879-887.

Tinner, W. and Lotter, A.F. 2001: Central European vegetation response to abrupt climate change at 8.2 ka. Geology 29, 551-554.

Tinner, W. and Lotter, A.F. 2006: Holocene expansions of Fagus silvatica and Abies alba in Central Europe: where are we after eight decades of debate? Quaternary Science Reviews 25, 526-549.

Turon, J.-L. 1984: Le palynoplancton dans l'environnement actuel de l'Atlantique nord-oriental. Evolution climatique et hydrologique depuis le dernier maximum glaciaire. PhD Thesis, Bordeaux University, France, $313 \mathrm{pp}$.

Van der Kaars, S. and de Deckker, P. 2003: Pollen distribution in marine surface sediments offshore Western Australia. Review of Palaeobotany and Palynology 124, 113-129.

Van Geel, B. van der Plicht, J. and Renssen, H. 2003: Major $\Delta^{14} \mathrm{C}$ excursions during the late glacial and early Holocene: changes in ocean ventilation or solar forcing of climate change? Quaternary International 105, 71-76.

Veski, S., Seppä, H. and Ojala, A.E.K. 2004: The cold event 8200 years ago recorded in annually laminated lake sediments in Eastern Europe. Geology 32, 681-684.

Visset, L., Cyprien, A.L., Carcaud, N., Ouguerram, A., Barbier, D. and Bernard, J. 2002: Les prémices d" une agriculture diversifiée à la fin du Mésolithique dans le Val de Loire (Loire armoricaine, France). Comptes Rendus Palevol 1, 51-58.

Von Grafenstein, U., Erlenkeuser, H., Muller, J., Jouzel, J. and Johnsen, S. 1998: The cold event 8200 years ago documented in oxygen isotope records of precipitation in Europe and Greenland. Climate Dynamics 14, 73-81.

Von Grafenstein, U., Erlenkeuser, H., Brauer, A., Jouzel, J. and Johnsen, S. 1999: A mid-European decadal isotope-climarte record from 15000 to 5000 years BP. Science 284, 1654-1657.

Weber, S.L. and Oerlemans, J. 2003: Holocene glacier variability: three case studies using an intermediate-complexity climate model. The Holocene 13, 353-363.

Wiersma, A.P. and Renssen, H. 2005: Model-data comparison for the 8.2 ka BP event: confirmation of a forcing mechanism by catastrophic drainage of Laurentide Lakes. Quaternary Science Reviews 25, 6388. 


\section{Tables}

Table I. Radiocarbon ages from "VK03-58Bis" and "VK03-58" and "VK03-59Bis" shelf cores.

\begin{tabular}{|c|c|c|c|c|c|c|c|c|}
\hline Lab code & $\begin{array}{l}\text { Core- depth } \\
(\mathrm{cm})\end{array}$ & Material & $\begin{array}{l}\text { Conventional } \\
\text { AMS }{ }^{14} \mathrm{C} \\
\text { age BP }\end{array}$ & $\begin{array}{l}\text { Conv. } \\
\text { AMS }{ }^{14} \mathrm{C} \\
\text { age BP } \\
(-400 \mathrm{yr})\end{array}$ & error & $\begin{array}{l}\text { Weighte } \\
\mathrm{d} \\
\text { Mean } \Delta \mathrm{r} \\
\text { Arcacho } \\
\mathrm{n} \\
\text { France }\end{array}$ & $\begin{array}{l}95.4 \%(2 \sigma) \\
\text { Cal BP age } \\
\text { ranges }\end{array}$ & $\begin{array}{l}\text { Cal BP age } \\
\text { median } \\
\text { probability }\end{array}$ \\
\hline POZ-10166 & VK03 58Bis 106 & $\begin{array}{l}\text {. } \\
\text { communis }\end{array}$ & 3820 & 3420 & 30 & 3 & 3667 BP:3865 BP & 3763 \\
\hline POZ-10167 & VK03 58Bis 149 & $\begin{array}{l}T . \\
\text { communis }\end{array}$ & 7020 & 6620 & 30 & 3 & 7427 BP:7576 BР & 7507 \\
\hline POZ-10168 & VK03 58Bis 160 & $\begin{array}{l}T . \\
\text { communis }\end{array}$ & 8030 & 7630 & 30 & 3 & 8391 BP:8576 BP & 8479 \\
\hline POZ-10170 & VK03 58Bis 177 & $\begin{array}{l}T . \\
\text { communis }\end{array}$ & 8170 & 7770 & 30 & 3 & 8532 BP:8808 BP & 8652 \\
\hline POZ-10171 & VK03 58Bis 226 & $\begin{array}{l}T . \\
\text { communis }\end{array}$ & 8240 & 7840 & 30 & 3 & 8613 BP:8938 BP & 8764 \\
\hline POZ-6079 & $\begin{array}{l}\text { VK03 59Bis } 190 \\
\text { VK03 59Bis } 212\end{array}$ & $\begin{array}{l}T . \\
\text { communis } \\
T .\end{array}$ & 7920 & 7520 & 40 & 3 & 8298 BP:8476 BP & 8377 \\
\hline POZ- 10172 & & $\begin{array}{l}\text { communis } \\
T .\end{array}$ & 8200 & 7800 & 40 & 3 & 8567 BP:8884 BP & 8696 \\
\hline POZ -6077 & VK03-58 201 & communis & 8090 & 7690 & 50 & 3 & 8411 BP:8692 BP & 8545 \\
\hline
\end{tabular}

\section{Figures captions}

Figure 1. Location of shelf cores: A) "VK03-58Bis" and "VK03-58"; B) "VK03-58Bis"; and deep-sea core MD99-2551 (Ellison et al., 2006).

Figure 2. Age (cal yr BP)/ depth (cm) model of the "VK03-58Bis" record.

Figure 3. Lithology and synthetic pollen diagram against depth $(\mathrm{cm})$. From left to right: radiocarbon and calibrated ages; lithology (after Folliot, 2004) including T. communis level (represented by small shells); dinocyst percentages (Operculodnium centrocarpum; Total of Spiniferites and Lingulodinium machaerophorum); pollen diagram and pollen zones.

Figure 4. Simplified pollen diagram and quantitative pollen-based climate estimates plotted against depth $(\mathrm{cm})$. From left to right: calibrated ages; selected pollen taxa from the synthetic pollen diagram (other deciduous trees include: Fraxinus excelsior-type, Tilia and Ulmus); climate parameters: PANN (mean annual precipitation); difference between the temperature of the warmest (MTWA) and the coldest (MTCO) months (seasonality) and TANN (mean annual temperatures) and pollen zones. Dashed lines represent maxima (bold) and minima values and the dark line represents mean values of climate parameters estimates. Grey lines represent the tendency of each curve. 
Figure 5. Correlation between vegetation changes, quantitative climate estimates, summer insolation at $45^{\circ} \mathrm{N}$ and precessional signal (after Berger, 1978) and $\delta^{18} \mathrm{O}$-isotope composition of the NorthGRIP icecore (Johnsen et al., 2001) during the Holocene. Temperate and humid trees include: Acer, Alnus, Betula, Corylus, Cupressaceae, deciduous Quercus, Fagus, Fraxinus excelsior-type, Pinus, Quercus ilex-type, Salix, Tilia and Ulmus while Brassicaceae, Caryophyllaceae, Asteraceae (including Aster- and Anthemistypes) and Taraxacum-type, Cyperaceae, Ericaceae and Calluna, Plantago, Poaceae and semi-desert plants (including Chenopodiaceae, Artemisia and Ephedra) are integrated in the herbaceous plants association.

Figure 6. Correlation between selected pollen taxa, quantitative climate estimates (PANN, TANN, MTCO, MTWA and seasonality) and $\delta^{18} \mathrm{O}$-isotope composition of the NorthGRIP ice-core (Johnsen et al., 2001) during the Holocene. The $8.2 \mathrm{kyr}$ event is represented by the dark grey bar which is superimposed to 8.6$8.0 \mathrm{kyr}$ event represented by the light grey bar. Dark arrows indicate possible millennial-scale cooling events during the Holocene.

Figure 7. Present day and past marine biogeographical zones in the North-East Atlantic (adapted from Funder et al., 2002). Bold dashed lines represent the limits of the present-day marine biogeographical zones in the North-East Atlantic; Grey dashed lines represent: a) the northward displacement of the boreal southern limit during the early Eemian (Funder et al., 2002) and b) the southward displacement of the boreal southern limit during the during 8.6-8.0 kyr event (this work). 


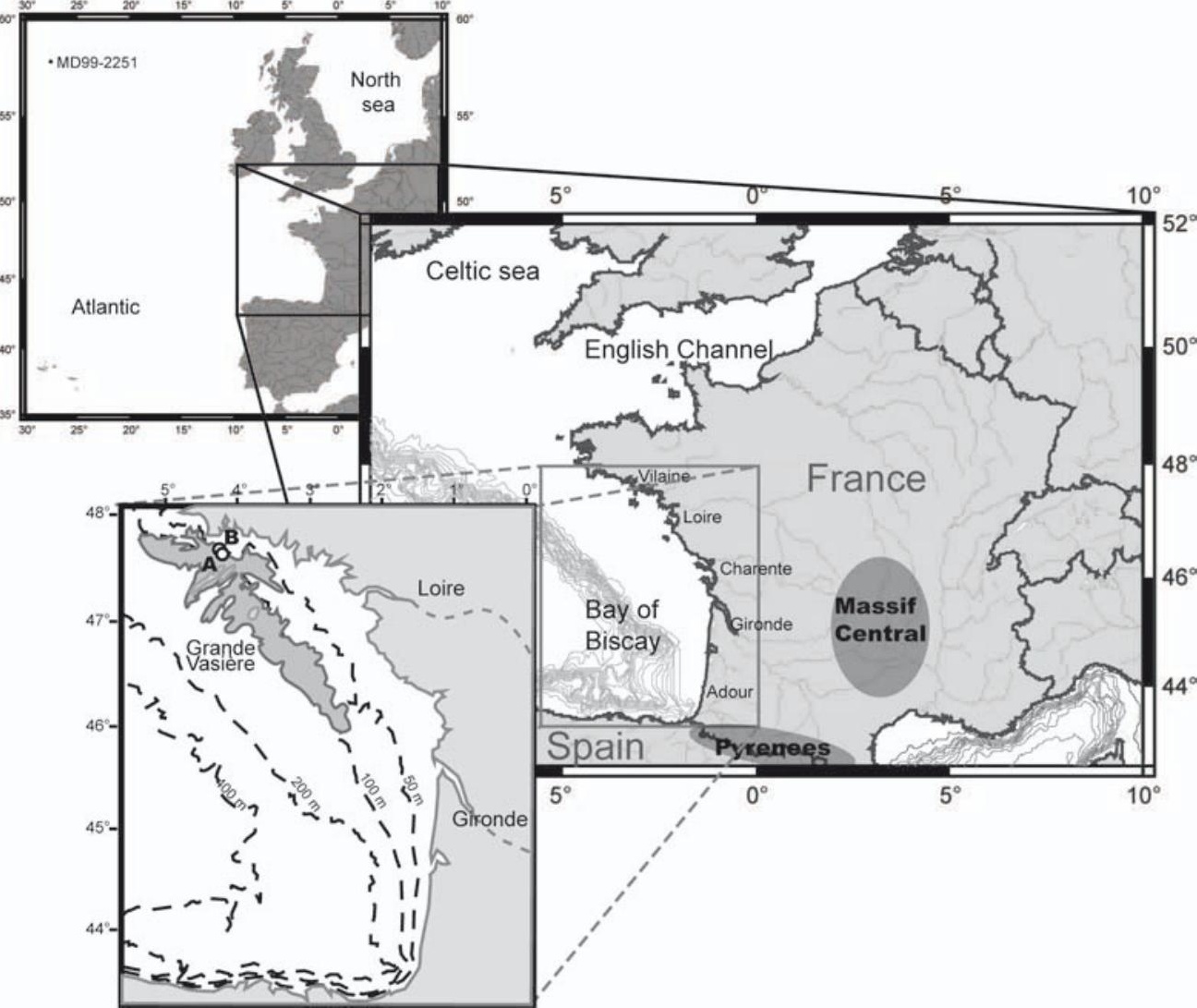


Age cal BP

$0 \quad 200040006000 \quad 800010000$

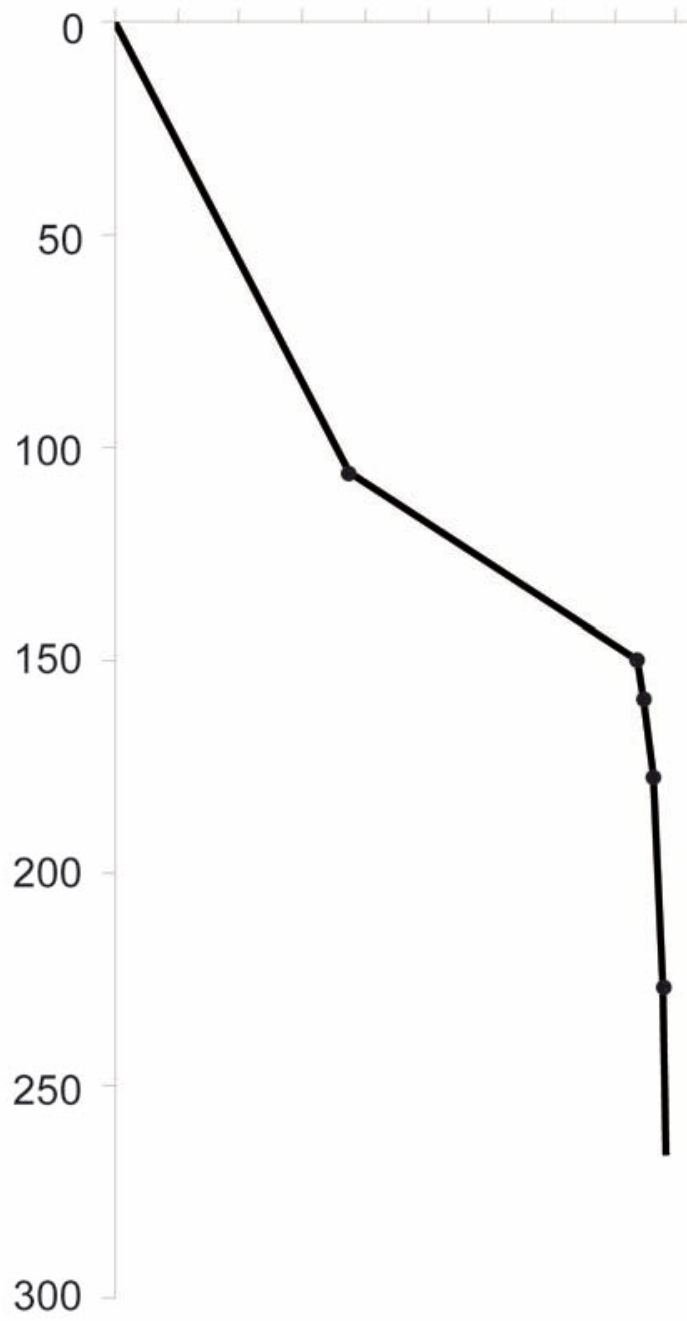




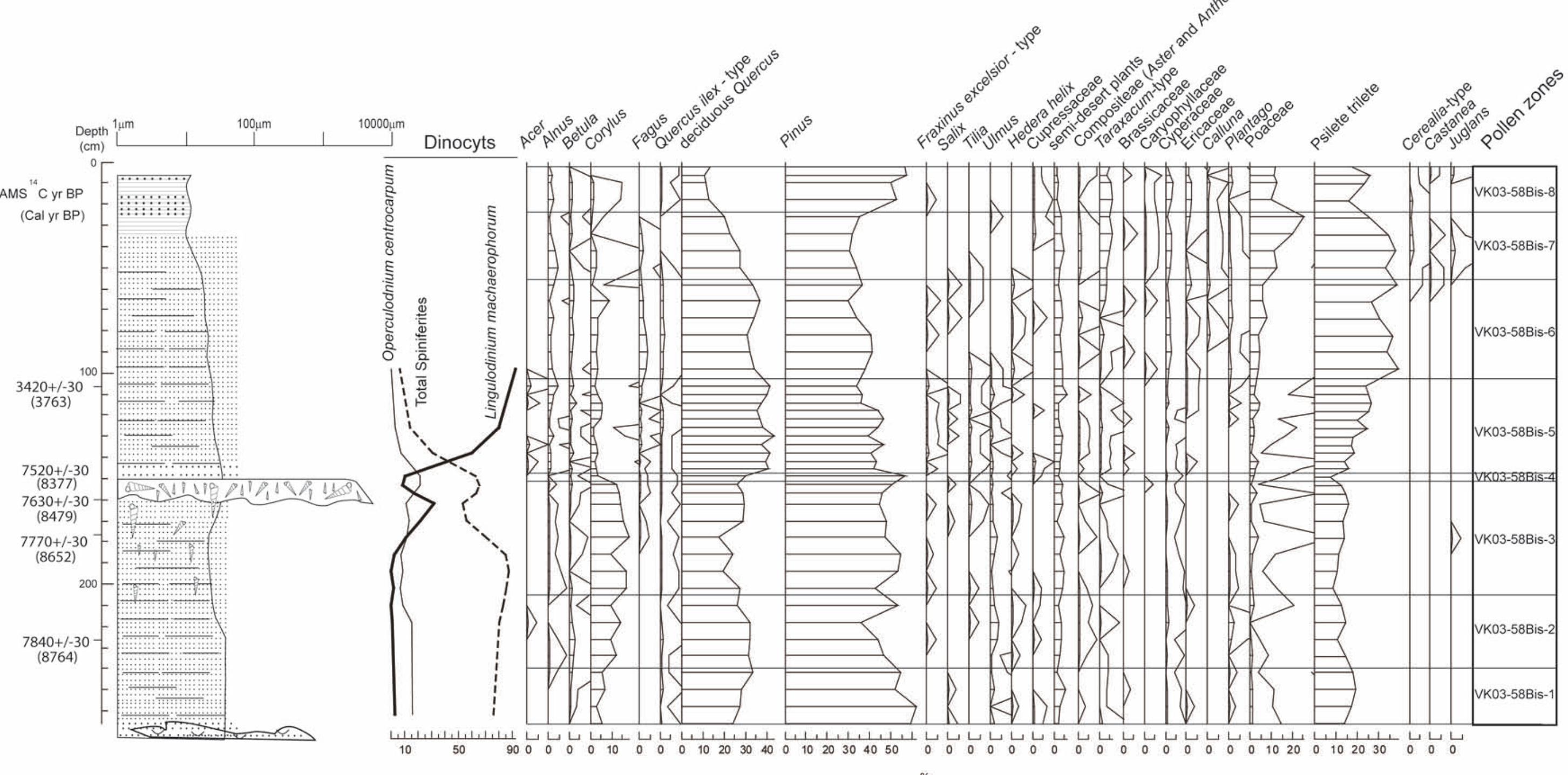

